Volume 4 • Nomor 2 • Februari 2021

Pege (Hal.) : 225 - 238

website. :

http://www.openjournal.unpam.ac.id/index.php/JPK
(C) Universitas Pamulang

JL.Surya Kencana No.1 Pamulang, Tangerang Selatan - Banten

Telp. (021) 7412566, Fax (021) 7412491 Email : jurnalmarketing.unpam@gmail.com

\title{
Pengaruh Citra Merk dan Kesadaran Merk Terhadap Keputusan Pembelian Tas Merk Bodypack Pada PT Eigerindo Multi Produk Industri ( Studi Kasus Di Showroom Mall Pejaten Vilage Jakarta Selatan )
}

\author{
Sugeng Widodo'; Apriyansyah ${ }^{2}$ \\ Universitas Pamulang, Email : dosen01632@unpam.ac.id
}

\begin{abstract}
Abstrak. Tujuan penelitian ini untuk mengetahui Pengaruh Citra Merk dan Kesadaran Merk terhadap Keputusan Pembelian Tas merk Bodypack pada Showroom Mall Pejaten Village Jakarta Selatan. Penelitian ini merupakan penelitian kuantitatif dengan menggunakan data primer dan data sekunder. Analisa data yang digunakan meliputi regresi linear berganda, uji $t$, uji $F$ dan uji koefisien determinasi. Hasil penelitian diperoleh bahwa secara parsial Citra Merk dan Kesadaran Merk berpengaruh signifikan terhadap keputusan pembelian. Secara simultan Citra Merk (X1) dan Kesadaran Merk (X2) berpengaruh signifikan terhadap Keputusan Pembelian (Y) dengan konstribusi sebesar $55 \%$ terhadap keputusan pembelian $(\mathrm{Y})$.
\end{abstract}

Kata Kunci: Citra Merk; Kesadaran Merk; Keputusan Pembelian

Abstract. The purpose of this study was to determine the effect of brand image and brand awareness on purchasing decisions for Bodypack brand bags at Showroom Mall Pejaten Village, South Jakarta. This research is a quantitative study using primary data and secondary data. The data analysis used includes multiple linear regression, $t$ test, $F$ test and coefficient of determination test. The results showed that partially brand image and brand awareness have a significant effect on purchasing decisions. Simultaneously Brand Image (X1) and Brand Awareness (X2) have a significant effect on Purchase Decisions (Y) with a contribution of 55\% to purchasing decisions $(Y)$..

Keywords: Brand Image; Brand Awareness; Purchase Decision

\section{A. PENDAHULUAN}

Keputusan pembelian keputusan pembelian dapat di artikan sebagai buah dari proses terjadinya transaksi jual beli. oleh karena itulah perusahaan dituntut untuk kreatif agar dapat memenangkan persaingan tersebut. Pembelian produk oleh konsumen juga dipegaruhi oleh citra merk. Citra merk pada dasarnya merupakan persepsi konsumen terhadap suatu merk tertentu yang di dasarkan atas pertimbangan dan memperlihatkan persepsi yang akurat dari suatu merk. Faktor berikutnya yang mempengaruhi keputusan pembelian adalah kesadaran merk. Kesadaran (awareness) mengambarkan keberadaan merk di dalam pikiran konsumen yang dapat menjadi penentu dalam beberapa kategori dan biasanya mempunyai peranan kunci dalam brand equity. Kesadaran merk (brand awareness) adalah kesanggupan seorang calon pembeli untuk mengenali atau mengingat kembali bahwa suatu merk merupakan bagian dari kategori tertentu maksud dari pengertian tersebut adalah pemasaran merupakan sebuah proses 
dimana perusahaan menciptakan nilai bagi pelanggan dan membangun pelanggan yang kuat untuk menangkap nilai dari pelanggan sebagai imbalan. Banyaknya Pesaing Produk tas yang menjual produk sejenis Membuat PT. Eigerindo Multi Produk Industri (Bodypack) harus mampu bersaing dengan para pelaku bisnis tersebut. Berikut adalah tabel Top Brand Index tahun 2020.

Tabel 1

Top Brand index Tas Tahun 2020

\begin{tabular}{|l|l|r|l|}
\hline No & Merek & TB & TOP \\
\hline 1 & Export & $16,2 \%$ & TOP \\
\hline 2 & Eiger & $16,1 \%$ & TOP \\
\hline 3 & Reebox & $14,0 \%$ & TOP \\
\hline 4 & Adidas & $3,6 \%$ & \\
\hline 5 & Nike & $2,4 \%$ & \\
\hline 6 & Bodypack & $2,3 \%$ & \\
\hline 7 & Converse & \\
\hline
\end{tabular}

Sumber: $h$ ttp://www.topbrand-award.com

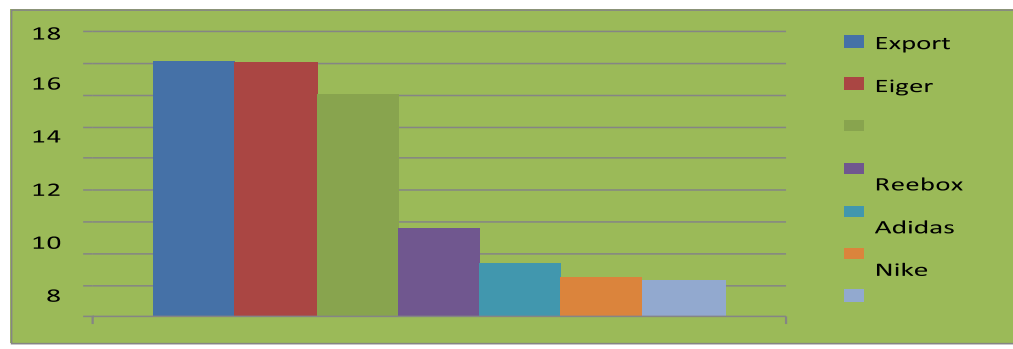

\section{Gambar 1 \\ Grafik Top Brand Index Tas Tahun 2020}

\section{B. KAJIAN LITERATUR}

\section{Kesadaran Merk}

Menurut Ambadar dalam Melynda, Srikandi dan Edy (2014:3) "Kesadaran Merk adalah ukuran kekuatan eksistensi suatu merek di benak konsumen mencakup brand recognition (merek yang pernah diketahui konsumen), brand recall (merek apa saja yang pernah diingat oleh pelanggan untuk kategori tertentu), top of mind (merk pertama apa yang disebut pelanggan untuk satu produk tertentu) dan dominant brand (satu-satunya merek yang diingat pelanggan)".

\section{Citra Merek}

Menurut Rahman (2013:182), "citra merek adalah merupakan persepsi atau pendapat konsumen yang muncul ketika mengingat sebuah produk tertentu". Kotlerr \& Keller (2016:345), "citra merek sebagai sekumpulan persepsi dan kepercayaan yang dimiliki oleh pelanggan terhadap suatu brand yang direfleksikan melalui asosiasi-asosiasi yang ada dalam ingatan pelanggan". Sedangkan Supranto \& Limakrisma (2013:176), "citra merek adalah apa yang konsumen pikir dan rasakan ketika mendengar atau melihat suatu merek dan apa yang konsumen pelajari tentang merek". 


\section{Keputusan Pembelian}

Menurut Assauri (2012:141), "keputusan pembelian adalah proses pengambilan keputusan pembelian yang melibatkan menentukan apa yang akan atau tidak akan dibeli, dan keputusan itu berasal dari tindakan masa lalu yang didapat dari pelanggan itu sendiri". Sedangkan Kotler \& Amstrong (2014), "keputusan pembelian adalah suatu proses penyelesaian masalah yang terdiri dari menganalisa atau pengenalan kebutuhan dan keinginan, pencarian informasi, penilaian sumber-sumber seleksi terhadap alternatif pembelian, keputusan pembelian, dan perilaku setelah pembelian". Berikut Kerangka berfikir dalam penelitian ini :

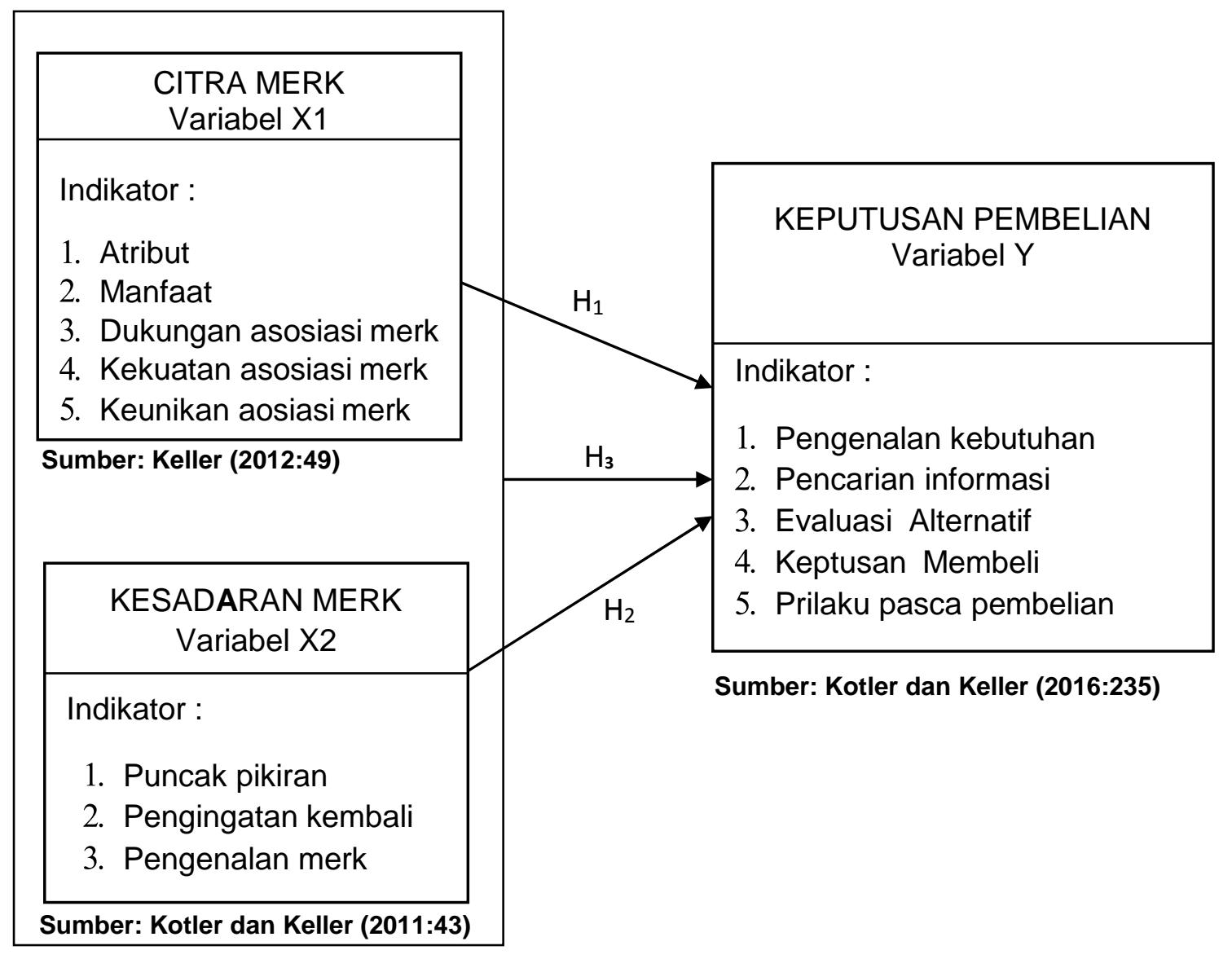

Gambar 2.

Kerangka Berfikir

\section{METODOLOGI PENELITIAN}

Penelitian ini merupakan penelitian asosiatif kuantitatif. Penelitian yang bertujuan untuk mengetahui pengaruh ataupun juga hubungan antara dua variabel atau lebih" (Sugiyono: 2013, p.11). Data yang diperoleh dari penelitian berbentuk angka dan penelitian ini bersifat deskriptif dan cenderung menggunakan analisa. Adapun populasi dalam peneltian ini adalah Konsumen Bodypack pada Showroom Mall Pejaten Village Jakarta tahun 2020 sebanyak 6.500 orang.

Penentuan jumlah sampel menggunakan rumus Slovin: 
ISSN NO. (PRINT) 2598-0823, (ONLINE) 2598-2893

$$
\mathrm{n}=\frac{\mathrm{N}}{\left(1+\mathrm{N} \cdot \mathrm{Moe}^{2}\right)}=\frac{6 \cdot 500}{(1+6 \cdot 500 \cdot 012)}=98,48
$$

Dimana:

$\mathrm{n}$ = Jumlah Sampel

$\mathrm{N}=$ Jumlah Populasi

Moe $=$ Margin of error atau kesalahan maksimal (10\%)

Hasil perhitungan di atas diperoleh jumlah sampel minimum sebanyak 98,48 dan dalam penelitian ini diambil sampelnya sebanyak 100 orang.

\section{HASIL DAN PEMBAHASAN}

Dalam penelitian ini kami menggunakan uji dengan hasil sebagai berikut :

\section{Uji Validitas}

"Suatu kuesioner dikatakan valid jika pertanyaan atau pernyataan pada kuesioner mampu mengungkapkan sesuatu yang akan diukur oleh kuesioner tersebut" Ghozali (2013:53). Untuk mengetahui validitas instrument maka nilai $r_{\text {hitung }}$ perlu dibandingkan $r_{\text {tabel }}$ dengan rumus untuk mencari $r_{\text {tabel }}$ adalah $(d f=N-2)$ df 100-2=98 Sehingga diperoleh $r_{\text {table }}$ dengan taraf Signifikansi 0.05 adalah 0.196 . Haisl uji dikatakan Valid jika nilai $r_{\text {hitung }}$

$$
\begin{aligned}
& r \text { hitung }>r \text { tabel }=\text { valid } \\
& r \text { hitung }<r \text { tabel }=\text { tidak valid }
\end{aligned}
$$

$>r_{\text {tabel }}$.

Tabel 2.

Hasil Uji Validitas

\begin{tabular}{|c|c|c|c|c|} 
Variabel & $\begin{array}{c}\text { Kode } \\
\text { Item }\end{array}$ & $\begin{array}{c}\mathrm{R} \\
\text { Hitung }\end{array}$ & $\begin{array}{c}\mathrm{R} \\
\text { Table }\end{array}$ & Keterangan \\
\hline \multirow{4}{*}{$\begin{array}{c}\text { Citra Merk } \\
\text { (X1) }\end{array}$} & $\mathrm{CM}-1$ & 0.715 & 0,196 & Valid \\
\cline { 2 - 5 } & $\mathrm{CM}-2$ & 0.67 & 0,196 & Valid \\
\cline { 2 - 5 } & $\mathrm{CM}-3$ & 0.695 & 0,196 & Valid \\
\cline { 2 - 5 } & $\mathrm{CM}-4$ & 0.511 & 0,196 & Valid \\
\cline { 2 - 5 } & $\mathrm{CM}-5$ & 0.764 & 0,196 & Valid \\
\cline { 2 - 5 } & $\mathrm{CM}-6$ & 0.617 & 0,196 & Valid \\
\cline { 2 - 5 } & $\mathrm{CM}-7$ & 0.637 & 0,196 & Valid \\
\cline { 2 - 5 } & $\mathrm{CM}-8$ & 0.659 & 0,196 & Valid \\
\cline { 2 - 5 } & $\mathrm{CM}-9$ & 0.735 & 0,196 & Valid \\
\cline { 2 - 5 } & $\mathrm{CM}-10$ & 0.638 & 0,196 & Valid \\
\cline { 2 - 5 } & $\mathrm{CM}-11$ & 0.429 & 0,196 & Valid \\
\cline { 2 - 5 } & $\mathrm{CM}-12$ & 0.506 & 0,196 & Valid \\
\hline & $\mathrm{KM} 1$ & 0.739 & 0,196 & Valid \\
\hline
\end{tabular}


ISSN NO. (PRINT) 2598-0823, (ONLINE) 2598-2893

\begin{tabular}{|c|c|c|c|c|}
\hline Variabel & $\begin{array}{c}\text { Kode } \\
\text { Item }\end{array}$ & $\begin{array}{c}\mathrm{R} \\
\text { Hitung }\end{array}$ & $\begin{array}{c}\mathrm{R} \\
\text { Table }\end{array}$ & Keterangan \\
\hline \multirow{5}{*}{$\begin{array}{c}\text { Kesadaran } \\
\text { Merk (X2) }\end{array}$} & $\mathrm{KM} 2$ & 0.748 & 0,196 & Valid \\
\cline { 2 - 5 } & $\mathrm{KM} 3$ & 0.751 & 0,196 & Valid \\
\cline { 2 - 5 } & $\mathrm{KM} 4$ & 0.713 & 0,196 & Valid \\
\cline { 2 - 5 } & $\mathrm{KM} 5$ & 0.732 & 0,196 & Valid \\
\cline { 2 - 5 } & $\mathrm{KM} 6$ & 0.593 & 0,196 & Valid \\
\cline { 2 - 5 } & $\mathrm{KM} 7$ & 0.671 & 0,196 & Valid \\
\cline { 2 - 5 } & $\mathrm{KM} 8$ & 0.669 & 0,196 & Valid \\
\cline { 2 - 5 } $\begin{array}{c}\text { Keputusan } \\
\text { Pembelian (Y) }\end{array}$ & $\mathrm{KM} 9$ & 0.785 & 0,196 & Valid \\
\cline { 2 - 5 } & $\mathrm{KP} 1$ & 0.613 & 0,196 & Valid \\
\cline { 2 - 5 } & $\mathrm{KP} 2$ & 0.739 & 0,196 & Valid \\
\cline { 2 - 5 } & $\mathrm{KP} 3$ & 0.735 & 0,196 & Valid \\
\cline { 2 - 5 } & $\mathrm{KP} 4$ & 0.607 & 0,196 & Valid \\
\cline { 2 - 5 } & $\mathrm{KP} 6$ & 0.771 & 0,196 & Valid \\
\cline { 2 - 5 } & $\mathrm{KP} 7$ & 0.656 & 0,196 & Valid \\
\cline { 2 - 5 } & $\mathrm{KP} 8$ & 0.729 & 0,196 & Valid \\
\cline { 2 - 5 } & $\mathrm{KP} 9$ & 0.663 & 0,196 & Valid \\
\hline \multirow{5}{*}{} & & & \\
\hline
\end{tabular}

Kesimpulan pengujian dari tabel uji validitas di atas, diperoleh bahwa semua nilai $t_{\text {hitung }}$ lebih besar dari nilai $t_{\text {tabel }}$ artinya semua indikator instrumen dinyatakan valid.

\section{Uji Reliabilitas}

Menurut Azwar (2014) "reliabilitas merupakan penerjemahan dari kata reliability Cara pengukurannya adalah seluruh item pernyataan yang telah valid dimasukan dan di ukur koefesien cronbach alpha, jika hasil yang diperoleh lebih besar dari 0.60 maka kuisioner dinyatakan telah reliable/konsisten".

Dasar pengambilan keputusan:

$\begin{array}{r}\text { Cronbach alpha } \mathrm{Ca}>0,60=\text { Reliabel } \\ \mathrm{Ca}<0,60=\text { tidak reliabel } \\ \hline\end{array}$

Tabel 3.

Uji Reliabilitas

\begin{tabular}{|l|r|c|c|}
\hline \multicolumn{1}{|c|}{ Variabel } & $\begin{array}{c}\text { Cronbach's } \\
\text { Alpha }\end{array}$ & Kriteria & Keterangan \\
\hline Citra Merek (X1) & 0.864 & 0.6 & Reliabel \\
\hline Kesadaran Merk (X2) & 0.878 & 0.6 & Reliabel \\
\hline Keputusan Pembelian (Y) & 0.861 & 0.6 & Reliabel \\
\hline
\end{tabular}


Dari hasil perhitungan realibilitas skala masing-masing konstruk ditunjukkan dengan koefisien cronbach's Alpha sebesar 0,864, citra merk, 0,878, kesadaran merk, dan 0,861 untuk keputusan pembelian. Karena hasil uji seluruhnya nilai cronbach's Alpha (Ca) > 0.60 maka dapat disimpulkan bahwa instrumen variabel reliabel.

\section{Uji Pesyaratan Data (Asumsi Klasik)}

\section{a. Uji Normalitas}

Uji ini bertujuan untuk membuktikan bahwa seluruh data yang digunakan terdistribusi normal. Pengujian yang digunakan menggunakan metode uji One Sample Kolmogorov - Smirnov.

Dasar pengambilan keputusan:

a. "Jika nilai signifikansi (sig.) $>0.05$ maka data penelitian berdistribusi normal.

b. Jika nilai signifikansi (sig.) < 0.05 maka data penelitian tidak berdistribusi normal" (Sofyan Siregar, (2014:167).

Tabel 4 Uji Normalitas

One-Sample Kolmogorov-Smirnov Test

\begin{tabular}{|c|c|c|c|c|c|}
\hline & & $\begin{array}{l}\text { Citra } \\
\text { Merk } \\
(\mathrm{X} 1)\end{array}$ & $\begin{array}{l}\text { Kesadaran } \\
\text { Merk (X2) }\end{array}$ & $\begin{array}{c}\text { Keputusan } \\
\text { pembelian } \\
\text { (Y) }\end{array}$ & $\begin{array}{l}\text { Unstandarliz } \\
\text { ed Residual }\end{array}$ \\
\hline \multirow{3}{*}{$\begin{array}{l}\text { Normal } \\
\text { Parametersa.b }\end{array}$} & & 100 & 100 & 100 & 100 \\
\hline & Mean & 421,200 & 314,600 & 332,200 & .0000000 \\
\hline & $\begin{array}{l}\text { Std. } \\
\text { Deviation }\end{array}$ & 695,771 & 642,505 & 551,871 & $271,518,333$ \\
\hline Most Extreme & Absolute & .076 & .059 & .070 & .050 \\
\hline \multirow[t]{2}{*}{ Differences } & Positive & .057 & .059 & .070 & .050 \\
\hline & Negative & -.076 & -.058 & -.063 & -.033 \\
\hline Test Statistic & & .076 & .059 & .070 & .050 \\
\hline $\begin{array}{l}\text { Asymp. Sig. } \\
\text { (2-tailed) }\end{array}$ & & $.166 c$ & $200 \underline{\underline{c, d}}$ & $200 \underline{\underline{c, d}}$ & $200 \underline{\underline{c, d}}$ \\
\hline
\end{tabular}

Dari output di atas dapat diketahui bahwa nilai signifikansi Citra Merk (X1) sebesar 0,166, Kesadaran Merk (X2) sebesar 0,200, Keputusan Pembelian (Y) sebesar 0,200 dan nilai signifikansi (Asymp sig 2-tailed) sebesar 0,200. Karena nilai signifikansi lebih besar dari 0,05, maka nilai residual terdistribusi normal.

Menurut Siregar (2014:153) "tujuan dilakukan uji normalitas terhadap serangkaian data adalah untuk mengetahui apakah populasi data berdistribusi normal atau tidak. Bila berdistribusi normal, maka dapat digunakan uji statistik berjenis parametrik. Sedangkan bila data tidak berdistribusi normal, maka digunakan uji statistik non parametrik. Untuk menguji apakah data berdistribusi normal atau tidak dilakukan uji statistik dengan tiga metode", yaitu: 


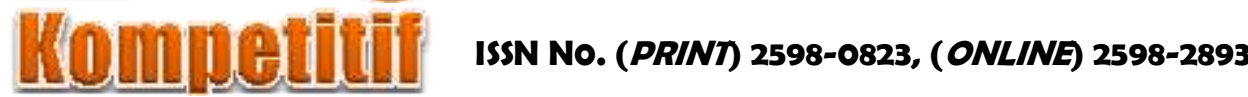

\section{a) Metode P-Plot}

"Metode yang lebih handal dalam uji normalitas adalah dengan melihat probability plot yang membandingkan distribusi kumulatif dari distribusi normal. Jika distribusi data residual normal, maka garis yang menggambarkan data sesungguhnya akan mengikuti garis diagonalnya" Ghozali (2016:154).

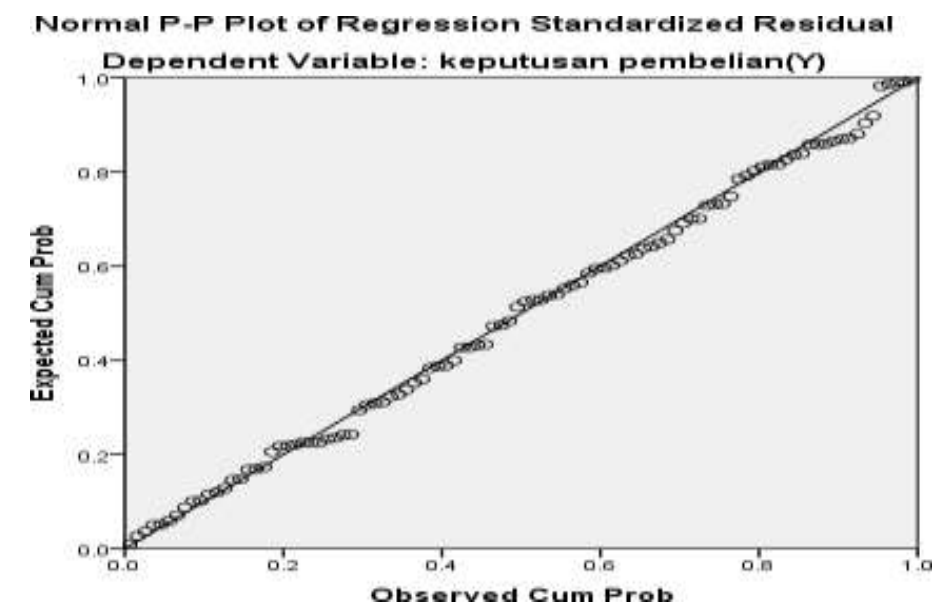

Gambar 3.

P-Plot Uji Normalitas-Diagram Penyebaran Titik Residual

Melihat grafik normal P-Plot terlihat titik-titik menyebar mengikuti arah garis diagonal, hal ini disimpulkan bahwa regresi memenuhi asumsi normalitas.

\section{b) Metode Histogram}

Metode Histogram melihat grafik histogram, yang membandingkan antara data observasi dengan distribusi yang mendekati distribusi normal.

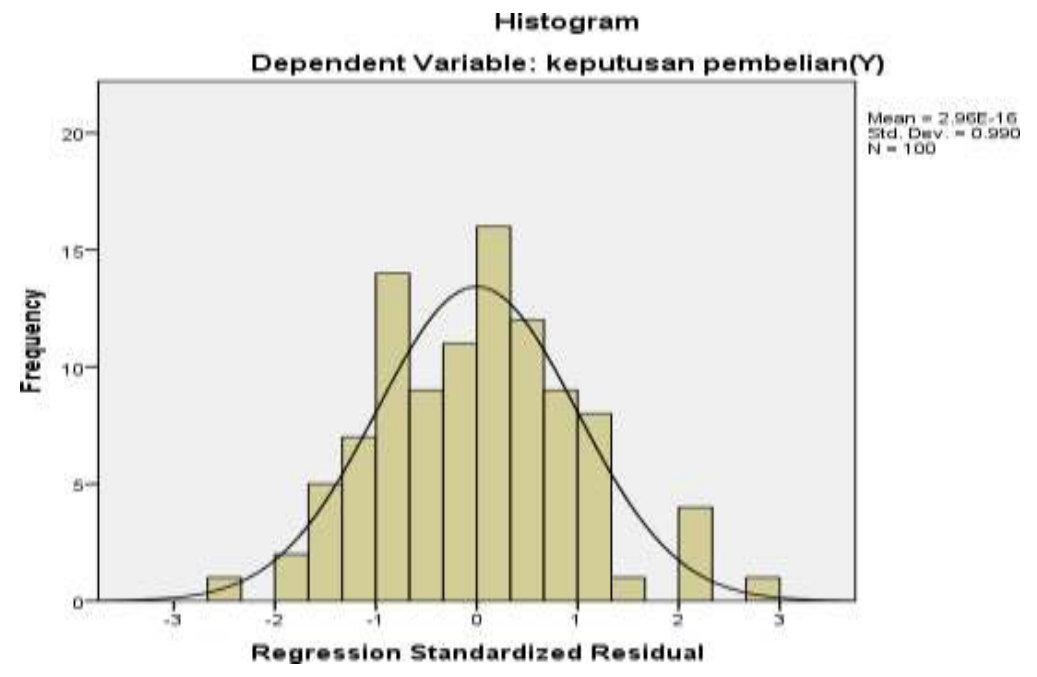




\section{Gambar 4 \\ Grafik Histogram Uji Normalitas}

Melihat grafik Histogram terlihat menunjukkan pola distribusi normal karena grafik tidak miring ke kiri maupun miring ke kanan, hal ini disimpulkan bahwa regresi memenuhi asumsi normalitas.

\section{Uji Multikolinearitas}

Tujuan uji multikoliniearitas adalah untuk mengetahui apakah model regresi ditemukan adanya korelasi antar variabel bebas (independen). Untuk menunjukkan adanya multikolinieritas dapat diketahui dengan melihat nilai tolerance $\geq 0,1$ atau sama dengan nilai $\mathrm{VIF} \leq 10$. Berikut hasi pengujian multikolinearitas:

Tabel 5 Hasil Uji Multikolinieritas

\begin{tabular}{|c|c|c|}
\hline \multirow{2}{*}{ Model } & \multicolumn{2}{|l|}{ Collinearity Statistics } \\
\cline { 2 - 3 } & Tolerance & VIF \\
\hline (Constant) & & \\
\hline Citra Merk & .517 & 1,934 \\
\hline Kesadaran Merk & .517 & 1,934 \\
\hline
\end{tabular}

Berdasarkan tabel di atas diperoleh nilai tolerance untuk ke dua variabel citra merk dan kesadaran merk diperoleh nilai $0 \mathrm{~m} 7=517>10 \%(0,10)$ dan nilai VIF (variance inflation factor) bernilai kurang dari 10 yakni di peroleh nilai 1,934, artinya pada mode tidak terjadi multikolinieritas.

\section{Uji Heteroskedastisitas}

Menurut Ghozali (2013:134) "Uji heteroskedastisitas yaitu untuk menguji apakah dalam model regresi terjadi ketidaksamaan variance dari residual satu pengamatan ke pengamatan yang lain. Dsar analisis untuk menentukan ada atau tidaknya heteroskedastisitas yaitu:

a. Jika ada pola tertentu, seperti titik - titik yang ada membentuk pola tertentu yang teratur (bergelombang melebar kemudian menyempit), maka mengindikasikan telah terjadi heteroskedastisitas.

b. Jika tidak ada pola yang jelas, serta titik-titik menyebar di atas dan di bawah angka 0 pada sumbu $\mathrm{Y}$, maka tidak terjadi heteroskedastisitas."

scatterplot

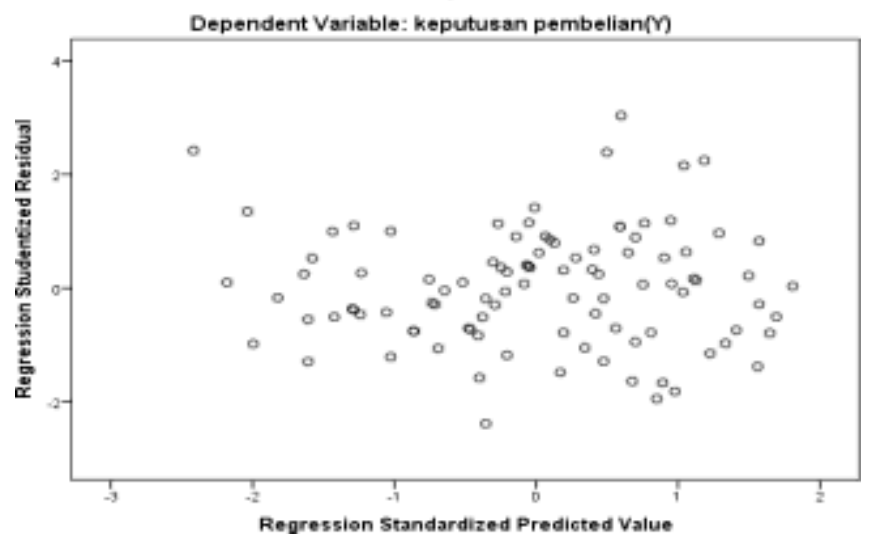




\section{Gambar 5 \\ Grafik Scaterplot Plot Uji Heteroskedastisitas}

Dari gambar di atas terlihat, titik-titik sebaran residual menyebar di atas dan di bawah angka 0 pada sumbu $Y$ dan tidak membentuk suatu pole tertentu. Artinya model regresi bebas dari heteroskedastisitas.

\section{Uji Autokorelasi.}

"Uji autokorelasi bertujuan menguji apakah dalam model regresi linear ada korelasi antara kesalahan pengganggu. Dalam penelitian ini digunakan metode Uji Durbin Watson (DW Test) dengn ketentuan nilai Durbin Waston berada diantara DU $<$ DW $<$ 4-DU". Ghozali, (2011:113)

Hasil uji autokorelasi, dapat penulis sajikan pada table dibawah ini:

Tabel 6. Uji Autokorelasi Model Summaryb

\begin{tabular}{|c|c|r|l|l|c|}
\hline Model & $\mathrm{R}$ & R Square & $\begin{array}{l}\text { Adjusted R } \\
\text { Square }\end{array}$ & $\begin{array}{l}\text { Std. Error of } \\
\text { the Estimate }\end{array}$ & $\begin{array}{c}\text { Durbin- } \\
\text { Watson }\end{array}$ \\
\hline 1 & $.871 \mathrm{a}$ & .758 & .753 & 274,303 & 2,074 \\
\hline
\end{tabular}

Nilai DW (Durbin Watson) sebesar 2,074 dibandingkan dengan nilai table Durbin Watson dengan signifikansi 0,05 pada jumlah sampel 100 dan jumlah variabel independen $2(\mathrm{~K}=2)$ didapatkan nilai $\mathrm{DU}=1,715$ dan $\mathrm{DL}=1,633$. Hasil pengambilan keputusan berada pada DU < DW < 4 - DU $(1,715<2,074<2,367)$ dapat disimpulkan karena nilai DW (Durbin Watson) sebesar 2,074 lebih besar dari batas atas (DU) 1,715 dan kurang dari 4 - 1,715 (4 - DU) berarti tidak terdapat autokorelasi.

\section{Uji Hipotesis}

\section{a. Uji Parsial (Uji t)}

Uji t pada dasarnya menunjukkan seberapa jauh pengaruh satu variabel independen secara individual terhadap variabel dependen. Dasar Pengambilan Keputusan:

Tabel 7. Uji Parsial (Uji t)

Coefficients $^{\mathrm{a}}$

\begin{tabular}{|c|c|c|c|c|c|}
\hline \multirow[b]{2}{*}{ Model } & \multicolumn{2}{|c|}{$\begin{array}{c}\text { Unstandardized } \\
\text { Coefficients } \\
\end{array}$} & \multirow{2}{*}{$\begin{array}{c}\begin{array}{c}\text { Standardized } \\
\text { Coefficients }\end{array} \\
\text { Beta } \\
\end{array}$} & \multirow[b]{2}{*}{$\mathbf{t}$} & \multirow[b]{2}{*}{ Sig. } \\
\hline & B & $\begin{array}{l}\text { Std. } \\
\text { Error }\end{array}$ & & & \\
\hline 1 (Constant) & 4.345 & 1.712 & & 2.538 & .013 \\
\hline citra merk $(\mathrm{X} 1)$ & .416 & .055 & .524 & 7.545 & .000 \\
\hline $\begin{array}{l}\text { kesadaran } \\
\text { merk(X2) }\end{array}$ & .361 & .060 & .421 & 6.054 & .000 \\
\hline
\end{tabular}


Berdasarkan tabel di atas dapat di jelaskan

1) Hasil perhitungan pengaruh parsial Citra Merek terhadap Keputusan Pembelian diperoleh nilai thitung $7.545>\mathrm{t}$ table 1,984 dengan Sig 0,00< 0,05 artinya terdapat pengaruh antara Citra Merk $\left(\mathrm{X}_{1}\right)$ terhadap keputusan pembelian(Y).

2) Hasil perhitungan pengaruh parsial Kesadaran Merk (X2) terhadap Keputusan Pembelian (Y) sebesar thitung $6.054>t$ table 1,984 atau Sig 0,00 $<0,05$ artinya terdapat pengaruh antara Kesadaran Merk (X2) terhadap keputusan pembelian (Y).

\section{a. Uji Simultan ( Uji F )}

Uji $F$ menunjukkan semua variabel independen mempunyai pengaruh secara bersama-sama terhadap variabel dependen. Kriteria pengambilan keputusanya dengan tingkat signifikansi ( 0.05 adalah dengan membandingkan nilai $F$ hitung dengan $\mathrm{F}$ table).

Tabel 8. Uji Simultan (Uji F)

\begin{tabular}{|l|r|r|r|r|r|}
\hline Model & $\begin{array}{r}\text { Sum of } \\
\text { Squares }\end{array}$ & Df & \multicolumn{1}{c|}{$\begin{array}{c}\text { Mean } \\
\text { Square }\end{array}$} & \multicolumn{1}{c|}{ F } & Sig. \\
\hline 1 Regression & 2285.310 & 2 & 1142.655 & 151.863 & $.000^{\mathrm{b}}$ \\
Residual & 729.850 & 97 & 7.524 & & \\
Total & 3015.160 & 99 & & & \\
\hline
\end{tabular}

Berdasarkan hasil Uji $F$ diatas diperoleh nilai signifikansi $0,00<0,05$ dan nilai Fhitung sebesar 151.863>Ftabel 3,09 sehingga dapat disimpulkan bahwa H3 di terima yang berarti terdapat pengaruh variable Citra merk (X1) dan variable kesadaran Merk (X2) secara simultan Terhadap variable keputusan pembelian $(Y)$.

\section{Uji Regresi Linear Sederhana}

"Analisis regresi linear sederhana adalah suatu alat analisis yang digunakan untuk mengukur pengaruh antara variabel bebas $(\mathrm{X})$ dan variabel terikat $(\mathrm{Y})$ " (Sugiyono, 2011).

\section{Tabel 9. Uji Regresi Linier Sederhana}

ANOVA $^{\mathrm{a}}$

\begin{tabular}{|ll|r|r|r|r|r|}
\hline Model & & Sum of Squares & Df & Mean Square & F & Sig. \\
\hline 1 & Regression & 2285.310 & 2 & 1142.655 & 151.863 & $.000^{\mathrm{b}}$ \\
& Residual & 729.850 & 97 & 7.524 & & \\
& Total & 3015.160 & 99 & & & \\
\hline
\end{tabular}

Berdasarkan tabel di atas diperoleh nilai $F$ hitung sebesar 151.863 dengan tingkat signifikansi sebesar 0,000 0,05 maka model regresi dapat di gunakan untuk memprediksi variable keputusan pembelian atau dengan kata lain terdapat pengaruh citra merek dan kesadaran merek $(X)$ terhadap Keputusan Pembelian 
$(\mathrm{Y})$.

\section{Uji Regresi Linear Berganda}

Analisis regresi berganda digunakan untuk memprediksi permintaan dimasa yang akan datang, berdasarkan data dimasa lalu atau untuk mengetahui pengaruh satu atau lebih variabel bebas (independent) terhadap satu variabel terikat (dependent).

Tabel 10. Uji Regresi Linier Berganda Coefficients $^{\mathrm{a}}$

\begin{tabular}{|c|c|c|c|c|c|}
\hline \multirow{2}{*}{ Model } & \multicolumn{2}{|c|}{$\begin{array}{l}\text { Unstandardized } \\
\text { Coefficients }\end{array}$} & \multirow{2}{*}{$\begin{array}{l}\text { Standardize } \\
\text { d } \\
\text { Coefficients } \\
\text { Bet } \\
\text { a } \\
\end{array}$} & \multirow{2}{*}{$\mathrm{T}$} & \multirow{2}{*}{ Sig. } \\
\hline & B & Std. Error & & & \\
\hline $\begin{array}{l}1 \text { (Constant) } \\
\text { citra merk }(\mathrm{X} 1)\end{array}$ & $\begin{array}{r}4.345 \\
.416 \\
\end{array}$ & $\begin{array}{r}1.712 \\
.055 \\
\end{array}$ & .524 & $\begin{array}{l}2.538 \\
7.545 \\
\end{array}$ & $\begin{array}{l}.013 \\
.000 \\
\end{array}$ \\
\hline $\begin{array}{l}\text { kesadar } \\
\text { an } \\
\text { merk(X2 } \\
\text { ) }\end{array}$ & .361 & .060 & .421 & 6.054 & .000 \\
\hline
\end{tabular}

Hasil regresi linear berganda diperoleh $Y=4.345+0,416+0,361+e$

1. Nilai Konstanta $=4,345$ yang artinya jika Citra Merek dan Kesadaran Merk nilainya 0 , maka keputusan pembelian akan bernilai sebesar 4.345.

2. Koefisien Regresi Citra Merek (X1) bernilai Positif sebesar 0,416 yang artinya jika variabel Citra Merek meningkat 1 satuan, maka akan meningkatkan keputusan pembelian sebesar 0,416 dengan asumsi variabel lain tetap.

3. Koefisien Regresi Kesadaran Merk (X2) bernilai positif sebesar 0,361 yang artinya jika variabel Kesadaran Merk meningkat 1 satuan, maka akan meningkat keputusan pembelian sebesar 0,361 dengan asumsi variabel lain tetap.

\section{Uji Determinasi}

Tabel 11. Uji Determinasi

Model Summary ${ }^{b}$

\begin{tabular}{|l|r|r|c|c|}
\hline Model & R & R Square & Adjusted R Square & $\begin{array}{c}\text { Std. Error of the } \\
\text { Estimate }\end{array}$ \\
\hline 1 & $.871^{\mathrm{a}}$ & .758 & .753 & 2.4303 \\
\hline
\end{tabular}

Sumber: Data diolah penulis, 2020

Berdasarkan table di atas diperoleh nilai $\mathrm{R}$ square sebesar 0,758 , artinya engaruh citra merk (X1) dan Kesadaran Merk (X2) secara simultan adalah sebesar 75,8\%. 


\section{Pembahasan}

\section{Pengaruh Citra Merek Terhadap Keputusan Pembelian}

Hasil perhitungan pengaruh citra Merek terhadap keputusan pembelian diperoleh nilai $t_{\text {hitung }} 7,545>t_{\text {table }} 1,984$ atau Sig 0,00 $<0,05$ maka Ho ditolak dan $\mathrm{Ha}$ diterima. Yang artinya citra merek berpengaruh terhadap keputusan pembelian. Hubungan citra merek terhadap keputusan pembelian adalah positif, hal ini sesuai dengan penelitian Dimana dari hasil penelitiannya menunjukkan bahwa citra merek berpengaruh signifikan terhadap Keputusan Pembelian.

\section{Pengaruh Kesadaran Merk Terhadap Keputusan Pembelian}

Hasil perhitungan pengaruh kesadaran merk terhadap keputusan pembelian mendapatkan nilai $t_{\text {hitung }} 6,054>t_{\text {table }} 1,984$ atau Sig 0,00 $<0,05$ maka Ho ditolak dan $\mathrm{Ha}$ diterima, yang artinya kesadaran merk berpengaruh terhadap keputusan pembelian.

\section{Pengaruh Secara Simultan (bersama-sama) antara Variabel Citra Merek (X1) dan kesadaran merk (X2) terhadap Keputusan Pembelian (Y).}

Hasil perhitungan pengaruh Citra merk dan Kesadaran merk terhadap keputusan pembelian diperoleh nilai Fhitung 151,863 > Ftabel 3,09 pada sig $\alpha 0,000<0.05$, maka $\mathrm{Ho}$ ditolak dan $\mathrm{Ha}$ diterima, maka dapat disimpulkan bahwa, terdapat pengaruh yang signifikan secara simultan (bersama-sama) antara variablel Citra Merek (X1) dan kesadaran merk (X2), terhadap Keputusan Pembelian (Y).

\section{E. KESIMPULAN}

Berdasarkan hasil dan pembahasan dapat ditarik kesimpulan sebagai berikut:

1. Terdapat pengaruh langsung dan signifikan antara variabel Citra Merk tehadap Keputusan Pembelian Tas merk Bodypack Pada Showroom mall pejaten Village Jakarta Selatan.

2. Terdapat pengaruh langsung dan signifikan antara variabel Kesadaran Merk terhadap Keputusan pembelian Pembelian Tas merk Bodypack Pada Showroom mall pejaten Village Jakarta Selatan.

3. Terdapat pengaruh langsung dan signifikan antara variabel Citra merk dan Kesadaran Merk terhadap keputusan pembelian Pembelian Tas merk Bodypack Pada Showroom mall pejaten Village Jakarta Selatan.

\section{DAFTAR PUSTAKA}

Amstrong, \& Kotler. (2015). "Marketing Of Introducing Prenticehall Twelfth Edition. England": Pearson Education.

Assauri, Sofian. (2014). "Manejemen Pemasaran”. Cetakan ke-11. Jakarta: PT Rajagrafindo.

Azwar, S. (2014). "Reliabilitas dan Validitas". Yogyakarta: Pustaka Pelajar

Daryanto. (2011). "Manajemen Pemasaran": Sari Kuliah, Bantung: Satu Nusa Dharma, S.A \& Sukatmadja. (2015). "Pengaruh Citra Merk, Kesadaran Merk dan 
Diakses 02 Januari 2021, dari https://www.topbrand-award.com/top-brand-index/ Ghozali, Imam. (2011). Aplikasi Analisis Multivariate dengan Program SPSS, Edisi Kelima. Semarang: Universitas Diponegoro.

Durianto, D, Sugiarto, \& Sitinjak. (2004). "Strategi Menaklukan Pasar Melalui Riset Ekuitas dan Perilaku Merk”. Jakarta: PT Gramedia Pustaka Utama.

Kotler, \& Keller. (2010). “Manajemen Pemasaran”. Jilid 1, Edisi 13, Jakarta: Erlangga.

Kotler, \& Keller. (2012). Manajemen Pemasaran”. Edisi 12, Jakarta: Erlangga. Kotler, \& Keller (2013). "Manajemen Pemasaran”. Edisi 12, Jakarta: Erlangga.

Kotler, Philip. (2014). "Manajemen Pemasaran”. Edisi Keempat belas, Jakarta: PT. Indeks.

Krisnawati, D. (2016). "Pengaruh Brand Awerness Terhadap Keputusan Pembelian Amdk Merk Aqua (Studi pada Masyarakat di Kota Bandung)". Jurnal Ekonomi, 4(1).

Kriyantono, Rachmat. (2006). "Teknik praktis Riset Komunikasi”. Jakarta: Kencana Prenada Media Group.

Lesmana, R. (2019). Analisis Strategi Bersaing PT Dwi Perkasa Mobiltama Pamulang untuk Meningkatkan Penjualan. JIMF (Jurnal IImiah Manajemen Forkamma), 3(1).

Lesmana, R., \& Hasbiyah, W. (2019). Model Analisis Kepuasan dan Loyalitas Wisatawan Lokal Studi Kasus pada Objek Wisata Kepulauan Seribu Jakarta. JIMF (Jurnal IImiah Manajemen Forkamma), 2(3).

Lesmana, R., Habiyah, W., \& Nabila, N. I. (2020). Peran Kepuasan Wisatawan Terhadap Loyalitas Wisatawan Pada Objek Wisata Kepulauan Seribu Jakarta. JIMF (Jurnal IImiah Manajemen Forkamma), 3(2).

Lesmana, R., Sunardi, N., Hastono, H., \& Widodo, A. S. (2021). Perceived Quality Membentuk Customer Loyalty via Brand Equity pada Pengguna Smartphone Merek Xiaomi di Tangerang Selatan. Jurnal Pemasaran Kompetitif, 4(2), 157-167.

Lesmana, R., Widodo, A. S., \& Sunardi, N. (2020). The Formation of Customer Loyalty From Brand Awareness and Perceived Quality through Brand Equity of Xiaomi Smartphone Users in South Tangerang. Jurnal Pemasaran Kompetitif, 4(1), 1-12.

Mahiri, E.A. (2017). "Pengaruh Brand Awarness dan Perceived Quality Terhadap Keputusan Pembelian Sepeda Motor Merk yamaha Pada PT Permata Motor Kadipaten". Jurnal IImiah Manajemen dan Akutansi, 4(1).

Sangadji, E.M, \& Sopiah. (2013). "Perilaku Konsumen": Pendekatan Pratis. Andi: Yogjakarta.

Santoso, I. (2016). "Peran Kualitas Produk Dan Layanan Harga Dan Atmosfiir Rumah Makan Cepat Saji Terhadap Keputusan Pembelian Dan Kepuasan Kunsumen". Jurnal Manajemen Teknologi, 5(1).

Schiffman \& Kanuk, (2007). "Perilaku Konsumen". Edisi Kedua, Jakarta: PT. 
Indeks Gramedia.

Setyosari, P. (2015). “Metode penelitian pendidikan \& pengembangan”. Jakarta: Prenadamedia Group.

Sugiyono (2012), "Statistik untuk penelitian”. Bandung: Alfabeta. Sugiyono (2014), Statistik untuk penelitian. Bandung: Alfabeta.

Sunardi, N., \& Lesmana, R. (2020). Konsep Icepower (Wiramadu) sebagai Solusi Wirausaha menuju Desa Sejahtra Mandiri (DMS) pada Masa Pandemi Covid-19. JIMF (Jurnal IImiah Manajemen Forkamma), 4(1).

Sunardi, N., Lesmana, R., Kartono, K., \& Rudy, R. (2020). Peran Manajemen Keuangan dan Digital Marketing dalam Upaya Peningkatan Omset Penjualan bagi Umkm Pasar Modern Intermoda Bsd City Kota Tangerang Selatan di Tengah Pandemi Covid-19. Jurnal Abdi Masyarakat Humanis, 2(1).

Sunyoto, Danang. (2014). "Dasar-Dasar Manajemen Pemasaran (Konsep, Strategi, dan Kasus)". Cetakan ke-1. Yogyakarta: CAPS (Center for Academic Publishing Service).

Surachman. (2008). "Dasar-Dasar Manajemen Merk (Alat Pemasaran Untuk Memenangkan Persaing)". Malang: Bayumedia Publishing.

Syahputra, A.G. (2017). "Pengaruh Citra Merek Terhadap Keputusan Pembelian Produk Smartphone OPPO Pada Mahasiswa Universitas Telkom". Jurnal Bisnis dan Iptek 10(2).

Tjiptono, Fandy dan Gregorius Chandra, "Service Quality and Statisfiation", Edisi tiga, Andi, Jakarta, 2012. 